\title{
Effect of Phytohormones and Other Dormancy Breaking Chemicals on Seed Germination of Inula racemosa Hook F. - A Critically Endangered Medicinal Plant of North Western Himalaya
}

\author{
Haleema Bano $^{1 *}$, Javeed I.A. Bhat ${ }^{1}$, F.A. Lone ${ }^{1}$, Faisal Noor ${ }^{2}$, \\ M. Ashraf Bhat ${ }^{3}$ and Nageena Nazir ${ }^{4}$ \\ ${ }^{1}$ Division of Environmental Sciences, ${ }^{2}$ Division of Vegetable Science, \\ ${ }^{3}$ Division of Genetics and Plant Breeding, ${ }^{4}$ Division of Agri.-Statistics, Sher-e-Kashmir \\ University of Agricultural Sciences and Technology of Kashmir, Shalimar-190025, Srinagar, \\ Jammu and Kashmir, India \\ *Corresponding author
}

\section{Ke y w ords \\ Seed germination, Chilling, Hormone, Endangered, Inula racemosa}

\section{Article Info}

Accepted: 10 February 2019 Available Online: 10 March 2019

\section{A B S T R A C T}

Inula racemosa Hook. f. is commonly called Pushkarmool, belongs to family Asteraceae. The plant is distributed in temperate alpine Himalayas at an altitude of $1,500-4,200 \mathrm{~m}$ from Kashmir to Kumaon, Afghanistan to Central Nepal. Pushkarmool is commercially a very important medicinal plant of the North Western Himalayas. The plant is used in Ayurveda as an expectorant, rejuvenator and immune modulator. Root powder is reportedly hypoglycemic and hypocholesterolemic in human subjects. The species is critically endangered because of the fragile nature of its habitat, habitat destruction, illegal harvesting from the wild source, high market demand and destructive harvesting practices. The objective of the present study was to develop effective pre-sowing treatments to improve the seed germination, and to reduce mean germination time, so that protocols for commercial production of the plant could be developed and natural populations restored to ensure proper conservation of the species. In the present study phytohormones and other seed dormancy breaking chemicals were used to investigate their effect on seed germination. The results revealed highest mean percentage of germination in chilling treatment $\mathrm{Ch}_{1}$ (30 day chilled seeds) followed by treatment $\mathrm{GA}_{3} 1$ (Gibbrellic acid, $10^{-3} \mathrm{M}$ ) in almost all day intervals, barring $16^{\text {th }}$ day interval where highest mean percentage of germination was observed in chilling treatment $\mathrm{Ch}_{2}$ (40 day chilled seeds) and least was observed in Com. 1 and control treatments. On $30^{\text {th }}$ day, the highest mean percentage of germination $\pm \mathrm{SE}(82 \pm 1.15)$ was observed in treatment $\mathrm{Ch}_{1}$ followed by $\mathrm{GA}_{3} 1$ $(79 \pm 1.73)$ and least $(24 \pm 1.15)$ was observed in treatment Com $.4\left(\mathrm{H}_{2} \mathrm{SO}_{4} / \mathrm{NAA} 2\right)$. However, no germination was observed treatments $\mathrm{K}_{1}$ (Potassium nitrate, $0.2 \%$,) and $\mathrm{K}_{2}$ (Potassium nitrate, 0.3 $\%$ ). Treatment $\mathrm{S}_{1}$ (Acid scarification for 1 min.) with mean percentage of germination $\pm \mathrm{SE}$ $(31 \pm 1.15)$ was at par with treatment $\mathrm{Com} 2\left(\mathrm{H}_{2} \mathrm{SO}_{4} / \mathrm{GA}_{3} 2\right)$, but was statistically different from all other treatments. All the treatments were statistically significant. On $28^{\text {th }}$ day, the highest mean percentage of germination $\pm \mathrm{SE}(82 \pm 1.15)$ was observed in treatment $\mathrm{Ch}_{1}$ followed by $\mathrm{Ch}_{2}(78 \pm 1.15)$ and $\mathrm{GA}_{3} 1(74 \pm 1.15)$ least $(23 \pm 1.15)$ was observed in treatment Com .4 . From day $14^{\text {th }}$ to day $26^{\text {th }}$, treatments $\mathrm{GA}_{3} 1$ and $\mathrm{GA}_{3} 2$ (Gibbrellic acid, $10^{-4} \mathrm{M}$ ) were statistically different from each other as well as from the rest of all other treatments. From day $6^{\text {th }}$ to day $18^{\text {th }}$, treatments NAA1 (Naphthalene acetic acid, $25 \mathrm{ppm}$ ) and NAA2 (Naphthalene acetic acid, $50 \mathrm{ppm}$ ) were at par with each other, but from day interval of $20^{\text {th }}$ to $26^{\text {th }}$ these treatments were statistically different from each other. Treatments were statistically significant on all day intervals. The germination study gives an insight into the measures to be taken to increase the efficiency of seed germination to ensure the conservation of the endangered species. 


\section{Introduction}

Germination is a critical stage in the life cycle of every crop plant and often controls population dynamics, with major practical implications. Seed germination is the critical stage for species survival (Huang et al., 2003 and Yang et al., 2008). Seed germination studies proved to be useful in development of conservation study (Kandari et al., 2007). Seeds may be non-dormant at maturity and thus germinate soon after dispersal if environmental conditions are favourable for them germinates. However, favourable conditions may not persist long enough for the resulting plant to become established. Seed dormancy prevents seeds from germinating under unfavorable conditions, thus reducing the chances of seedling mortality and there by contributing to the success of population regeneration (Gutterman, 2012). However, poor seed germination of viable seeds in several Himalayan plant species is experienced as a limiting factor in multiplication of plants at a large scale (Baskin and Baskin, 2014 and Nadeem et al., 2002).

Inula racemosa is commonly called Pushkarmool belongs to family Asteraceae. The plant is distributed in temperate alpine Himalayas at an altitude of 1,500- 4,200m from Kashmir to Kumaon, Afghanistan to Central Nepal (Firdous, et al., 2018). Pushkarmool is a very important medicinal plant of the North Western Himalayas (Anonymous, 1998 and Wani et al., 2006). The plant is used in Ayurveda as an expectorant and resolvent in indurations. It is considered as a 'Rasayana'(rejuvenator, immunomodulator) by Ayurvedic physicians. According to Bhavaprakasha the drug is bitter pungent in taste (Bhavaprakasha, 1961). The aqueous extract of the fresh or dry roots is given orally in rheumatic pains and liver problems.
Externally a paste or liniment is used for relieving pain. The root is also used in veterinary medicine as a tonic. The root forms an important ingredient of several polyherbal formulations for heart diseases and inflammatory conditions of spleen and liver. Along with Commiphora mukul, the drug combination called 'Pushkarguggulu' is a popular anti obesity, hypolipidemic indicated in cardiac ailments (Firdous et al., 2018). In Chinese medicine it is used for abdominal distension and pain, acute enteritis and bacillary dysentery (Pharmacopoeia Committee of the Ministry of Health 1995). Root powder is reportedly hypoglycemic and hypocholesterolemic in human subjects (Tripathy et al., 1979). It brought about a beneficial improvement in ECG of patients with Ischemic heart disease (IHD) (Tripathy et al., 1983). At $450 \mathrm{mg} / \mathrm{kg}$ it enhanced PGE2 like activity in isoproterenol induced myocardial ischemia in rabbits.

In combination with guggulu it is anti anginal and hypolipidemic in patients with IHD (Ramji et al., 1991). In multi herb combination with Terminalia arjuna and Commiphora mukul, it is reported to exert cardioprotective effect in isoproterenol induced myocardial ischemia in rats (Seth et al., 1998). Zhang et al., (2012) isolated sesquiterpenes from the roots of Inula racemosa Hook. f. and later they evaluated these compounds for their inhibition of LPSinduced nitric oxide production in RAW264.7 macrophages, and the results indicated that some compounds moderately inhibited nitric oxide production with IC50 values of $7.39 \pm$ $0.36,6.35 \pm 0.26$, and $5.39 \pm 0.18 \mu \mathrm{M}$, respectively. He et al., (2014) reported that the ethanol extract of $I$. racemosa roots and its constituent compounds have potential for use in the control of A. albopictus larvae.

The populations of the species in the entire North Western Himalayan range are 
witnessing a speedy decline in density, dwindling both in size and number (Shabir et al., 2010). The populations of the species in the entire north western Himalayan range are witnessing a speedy decline in density, dwindling both in size and number (Parvaiz et al., 2006).

As the species is a critically endangered because of the fragile nature of its habitat, habitat destruction, illegal harvesting from the wild source, great market demand and destructive harvesting practices, the objective of the present study was to develop effective pre-sowing treatments, to improve the seed germination, so that protocols for commercial production of the plant could developed and natural populations could be restored to ensure proper conservation of the species.

\section{Materials and Methods}

Seeds of Inula racemosa were collected at maturity from alpine natural populations from Mahadave hills of Kashmir Himalaya (3000 $4000 \mathrm{~m}$ asl) during August to September 20017. The seeds were air-dried for a fortnight at room temperature $\left(15 \pm 2^{\circ} \mathrm{C}\right)$ and then were stored at room temperature $\left(15 \pm 2^{\circ} \mathrm{C}\right)$. Seeds were washed with $0.1 \%$ mercuric chloride for 5-7 minutes and then with $70 \%$ alcohol for 1 minute and thoroughly rinsed with double distilled water and divided into groups of 50 seeds each.

\section{Physical treatment}

\section{Stratification/Chilling}

The surface sterilized seeds (using mercuric chloride) were soaked in distilled water for 24 hours and then subjected to chilling at low temperature $\left(3-4^{\circ} \mathrm{C}\right)$ for different durations [(Chilling treatment $(\mathrm{Ch}): \mathrm{Ch} 1=30$ days, $\mathrm{Ch} 2$ $=40$ days and Ch3 = 50 days) $]$ using Refrigerator (Make L.G.).

\section{Acid scarification/Sulphuric acid (H2SO4)} treatment

The seeds were treated with concentrated sulphuric acid for $1 \mathrm{~min}$ : S1 followed by thorough washing in distilled water. Sulphuric acid (Sigma) used was $99.9 \%$ pure.

\section{Chemical treatment}

\section{Potassium nitrate $\left(\mathrm{KNO}_{3}\right)$}

Surface-sterilized seeds were moistened with different concentrations of aqueous solution potassium nitrate $(\mathrm{K} 1=0.2 \%, \mathrm{~K} 2=0.3 \%)$ for 24 hours followed by germination on substratum moistened with different concentrations of aqueous solution potassium nitrate $(\mathrm{K} 1=0.2 \%, \mathrm{~K} 2=0.3 \%)$.

Gibbrellic acid and naphthalene acetic acid treatment

The surface sterilized seeds shall be kept submerged in aqueous solution of $\mathrm{GA}_{3}$ and NAA with a concentration of $10^{-3} \mathrm{M}$ and $10^{-4}$ $\mathrm{M}\left(\mathrm{GA}_{3} 1=10^{-3} \mathrm{M}, \mathrm{GA}_{3} 2=10^{-4} \mathrm{M}, \mathrm{NAA} 1=25\right.$ ppm, NAA2 $=50$ ppm) for 24 hours.

\section{Combined treatment (Combination of sulphuric acid and hormones)}

Seeds were treated with $\mathrm{H}_{2} \mathrm{SO}_{4}$ for $1 \mathrm{~min}$ followed by through washing and then soaking in solution of hormone $\left(\mathrm{GA}_{3}\right.$ solution and NAA solution) for 24 hours and subsequent germination on substratum moistened with $\mathrm{GA}_{3} \mathrm{~s}$ and NAA solution \{(Combined treatment (Com) $\mathrm{H}_{2} \mathrm{SO}_{4} / \mathrm{GA}_{3}$ : Com $1=\mathrm{H}_{2} \mathrm{SO}_{4} / \mathrm{GA}_{3} 1$, Com $2=\mathrm{H}_{2} \mathrm{SO}_{4} / \mathrm{GA}_{3} 2$ ) (Com) $\mathrm{H}_{2} \mathrm{SO}_{4} / \mathrm{NAA}$ : Com $3=\mathrm{H}_{2} \mathrm{SO}_{4} / \mathrm{NAA} 1$, Com $4=\mathrm{H}_{2} \mathrm{SO}_{4} / \mathrm{NAA} 2$ )

One treatment was kept as control (Cont). There were fifteen treatments; fifty seeds in triplicate were used for each treatment. The 
experiment was laid in complete randomized design (CRD) with 3 replications each. After the treatment, the seeds were subjected to germination test by allowing them to germinate on the moistened filter paper. The germination of the seeds was monitored over the next one and a half month at an average temperature of $15-20^{\circ} \mathrm{C}$. Observation on the no. of days taken for the first seed to germinate, total no of days for complete germination and the total no of seeds germinated were noted on regular basis. One way ANOVA was used to find out various statistical terms. The relative effectiveness of different physio-chemical and hormonal treatments in dormancy removal and germination improvement was calculated and the seedlings were transferred to the pots.

\section{Results and Discussion}

Seed germination is a complex process, which starts with the absorption of water, followed by a short pause, and ending with the synthesis and activation of enzymes. Germination is regulated through a series of interactions of hormonal and environmental factors, and this is possible only when appropriate conditions are met (Aticia et al., 2003). Germination occurs as a result of the partial exposure of the cotyledons of the seeds which permits the process of hydrolysis whereby hormones, increase nucleic acid metabolism and protein synthesis, are released (Uwaegbute, 1996). In the present study germination started in different treatments on different dates. It started on day $2^{\text {nd }}$ in chilling treatments $\mathrm{Ch}_{1}$ and $\mathrm{Ch}_{2}$ and was observed till $30^{\text {th }}$ day in all the treatments (Table 1). The highest mean percentage of germination was observed in chilling treatment $\mathrm{Ch}_{1}$ (30 day chilled seeds) followed by treatment GA31 in all most all day intervals and least was observed in Com. 1 or control treatments, barring $16^{\text {th }}$ day interval where highest mean percentage of germination was observed in chilling treatment $\mathrm{Ch}_{2}$.

On $30^{\text {th }}$ day, the highest mean percentage of germination $\pm \mathrm{SE}(82 \pm 1.15)$ was observed in treatment $\mathrm{Ch}_{1}$ followed by $\mathrm{GA}_{3} 1(79 \pm 1.73)$ and least $(24 \pm 1.15)$ was observed in treatment Com. 4. However, no germination was observed treatments $K_{1}$, and $K_{2}$ (Table 2 and 3). Chilling treatments $\mathrm{Ch}_{1}$ and $\mathrm{Ch}_{2}$ were at par with treatment $\mathrm{GA}_{3} 1$ and treatment $\mathrm{Ch}_{3}$ was at par with $\mathrm{GA}_{3} 2$. All the three chilling treatments were statistically different from each other as well as with the rest of other treatments. Treatment S1 with mean percentage of germination \pm SE $(31 \pm 1.15)$ was at par with treatment Com 2, but was statistically different from all other treatments. Treatment $\mathrm{GA}_{3} 1$ was at par with treatment $\mathrm{Ch}_{1}$ and $\mathrm{Ch}_{2}$ and $\mathrm{GA}_{3} 2$ was at par with treatment $\mathrm{Ch}_{3}$, but were statistically different from each other and from all other treatments. Treatment NAA1 and NAA2 were statistically different from each other as well as from the rest of other treatments. Treatment Com 1 and Com 2 were statistically different from each other as well as from the rest of other treatments. However, treatment Com 2 was at par with treatment S1. Treatments Com. 3 and Com. 4 were at par with each other, but were statistically different from other treatments. Control treatment was statistically different from other treatments. All the treatments were statistically significant and treatment $\mathrm{Ch}_{1}$ was the best treatment among all other treatments.

On $28^{\text {th }}$ day, the highest mean percentage of germination $\pm \mathrm{SE}(82 \pm 1.15)$ was observed in treatment $\mathrm{Ch}_{1}$ followed by $\mathrm{Ch}_{2}(78 \pm 1.15)$ and $\mathrm{GA}_{3} 1(74 \pm 1.15)$. Least germination $(23 \pm 1.15)$ was observed in treatment Com. 4 (Table 2 and 3). Chilling treatments $\mathrm{Ch}_{1}$ and $\mathrm{Ch}_{2}$ were at par with each other, treatment $\mathrm{Ch}_{2}$ was also at par with treatment $\mathrm{GA}_{3} 1$ but were statistically different from the rest of other 
treatments. Treatment S1 was at par with treatment Com 1, but was statistically different from all other treatments. Treatment $\mathrm{GA}_{3} 1$ was at par with treatment $\mathrm{Ch}_{2}$ and $\mathrm{Ch}_{2}$ and $\mathrm{GA}_{3} 2$ was at par with treatment $\mathrm{Ch}_{3}$, but were statistically different from each other and from all other treatments. Treatment NAA1 and NAA2 were statistically different from each other as well as from the rest of other treatments. Treatment Com 1 and Com 2 were was at par with treatment S1, however, treatment Com 2 was also at par with treatment Com. 3, but both treatments Com 1 and Com 2 were statistically different from each other as well as from the rest of other treatments. Treatments Com. 3 and Com. 4 were at par with each other, but were statistically different from all other treatments. Control treatment was statistically different from other treatments. All the treatments were statistically significant.

From day $14^{\text {th }}$ to day $26^{\text {th }}$, treatments $\mathrm{GA}_{3} 1$ and $\mathrm{GA}_{3} 2$ were statistically different from each other as well as from the rest of all other treatments. From day $6^{\text {th }}$ to day $18^{\text {th }}$, treatments NAA1 and NAA2 were at par with each other, but from day interval of $20^{\text {th }}$ to $26^{\text {th }}$ these treatments were statistically different from each other. Treatments were statistically significant on all day intervals.

The highest mean percentage of germination in chilling treatment $\mathrm{Ch}_{1}$ (30 day chilled seeds) in almost all day intervals may be because chilling performs a pivotal role in inducing the stimulus that is needed to surmount dormancy. It is regarded to initiate an increase in the concentration of gibberllic acid (Bretzloff and Pellett, 1979). Chilling is useful to relieve primary inactiveness of many Northern hemisphere species (Baskin, 2001). It has been commonly used as a pre-sowing treatment to overcome dormancy and enhance percentage of germination of dormant seeds of many different species (Fang et al., 2006).
The pre-chilling treatment conditions may actually be simulating the events that occur during the winter season just before the appearance of summer.

The next higher mean percentage of germination was observed in treatment GA31 (Fig. 1). It seems that pre chilling requirement in this species is replaced by gibberellin treatment, as it took only 30 days for complete germination. However, seeds were chilled for varying durations (1-month, 40days and 50 days) before observing their germination over a period of one month. So treatment of seeds with GA3 saves a time period of approximately one month. Similar results have been reported by Sharma et al., (2006) while studying the seed germination behavior of some medicinal plants species. However, our results were contradictory to Shabir et al., (2010) as they did not obtain any germination in gibberellin treated seeds. Gibberellins surmount seed and bud dormancy in many species, thus serving as a substitute for low temperatures, long days or red light (Salisbury and Ross, 1992). In the present study, this response to germination was influenced by proporition of applied GA3. At lower concentrations (GA32 $=10-4$ $\mathrm{M})$, germination was lower $(75 \%)$ and at higher concentration $(\mathrm{GA} 31=10-3 \mathrm{M})$, it was higher (80\%) (Table 1 and Fig. 1). Dormant seeds, which demand cold temperature treatment, dry storage following maturation as initiator or stimulator of germination are mostly treated with GA3 to surmount their dormancy (Nadjafi et al., 2006). Plant growth hormones are chemicals which in small quantities can regulate various plant processes in addition to seed dormancy. Different plant hormones can control different plant processes including seed dormancy and germination, growth and development of various plant parts (Agraeber et al., 2012). Gibberellins are mostly employed to destroy the low temperature requirements of some 
plant seeds and enhance their germination percentage (El-Dengawy, 2005). It plays a role in inducing enhancement of enzyme synthesis that changes stored nutrients carbohydrates, which are required for quick cell respiration during germination (Bakrim et al., 2007). Similar mean percentage of germination $\pm \mathrm{SD}(70 \pm 2.3)$ was observed in treatments $\mathrm{GA}_{3} 2$ (10-4 M) and $\mathrm{Ch}_{3}$ (50 day chilled seeds), respectively, again justifying the positive role of gibberellins in enhancement of germination.

Increase in germination per centage was reported by other workers from studies carried out on other species, such as Ferula gummosa (Nadjafi et al., 2006), Sesamum indicum (Kyauk et al., 1995) and Rumex dentatus (Ali et al., 1996).

Absence of germination in treatments $\mathrm{K} 1$ and $\mathrm{K}_{2}$ (KNO3, $0.1 \%$ and 0.2 ) may be because of the fact that application of nitrogen, in KNO3 form cause a toxic effect, thus inhibiting seed germination or this could be attributable to oxygen deficiency due to impermeable testa, or build-up of inhibitors as well as salinity (toxic effect) of the chemical $\left(\mathrm{KNO}_{3}\right)(\mathrm{Nego}$, 2015). Similar results have been reported by Fernández et al., (2006) while studying seed germination of Rumex crispus. Pérez Fernández and Rodríguez-Echeverría, 2003 on ten species of wood lands and Bhardwaj et al., (2016) in $I$. racemosa also found inhibition in seed germination by exogenous application of $\mathrm{KNO}_{3}$.

Low percentage of germination in sulphuric acid treated seeds $\left(S_{1}\right)$ (Fig. 1) may be because of the fact that acids have negative influence on seed germination. Conc. Sulphuric acid breaks the phospho-diester bonds, which serve as a backbone for DNA, resulting in damage to DNA and cells. Thus the embryo gets killed. Similar results were observed by Nasiri and Eisavand (2001) and
Shabir et al., (2010) while studying the influence of acidic treatments on germination of Ceratonia siliqua and $I$. racemosa, respectively. Contrary to the present findings, Saied et al., (2008) on Ziziphus, Khaleghi et $a l$. , (2009), on Tamarind, Nasiri and Eisavand (2001), on Albizia julibrissin and Hojati et al., (2007), on Cycas revolute Bhardwaj et al., (2016) on Inula racemosa had introduced sulfuric acid as the best treatment.

In naphthalene acid treated treatments NAA1 and NAA2, mean percentage of germination \pm SD $(66 \pm 21.6$ and $53 \pm 16.77)$ was higher as compared to control treatment $(41 \pm 14.19)$. Shinde et al., (1994) also reported increased percentage germination as well as seedling vigour with the exogenous application of naphthalene acetic acid (NAA). However, it was lower compared to gibberllic acid treated treatments GA31 (79 \pm 27.04$)$ and GA32 (70 \pm 23.30$)$ treatments. This is because of the positive effects of hormone naphthalene acetamide, (synthetic auxin that acts as a rootining harmone) on the seed coat as the partial exposure of the cotyledons of the seeds permits the process of hydrolysis whereby hormones such as auxins and ethylene, which could increase nucleic acid metabolism and protein synthesis, are released (Uwaegbute, 1996). Maku et al., (2014) also reported higher percentage of germination in $T$. tetraptera seeds when treated with naphthalene acetic acid (NAA).

In case of treatments Com $1\left(\mathrm{H}_{2} \mathrm{SO}_{4} / \mathrm{GA}_{3} 1\right)$ and Com. $2\left(\mathrm{H}_{2} \mathrm{SO}_{4} / \mathrm{GA}_{3} 1\right)$, mean percentage of germination \pm SD $\quad(37 \pm 11.84$ and $31 \pm 10.34)$ was lower compared to control treatment (41 14.19$)$. It may be because of the negative effect of sulphuric acid on seed germination. Similar was the case with treatments Com $3\left(\mathrm{H}_{2} \mathrm{SO}_{4} / \mathrm{NAA} 1\right)$ and Com. 4 $\left(\mathrm{H}_{2} \mathrm{SO}_{4} / \mathrm{NAA} 2\right)$. Our results are contradictory to Bhardwaj et al., (2016). They reported higher percentage of germination in acid 
treated treatments as compared to control treatment. As treatment of seeds with conc. sulphuric acid may be injurious to the seeds as acid may rapture vital parts of the embryo. According to Levitt (1974) and Nikoleave, (1977) immersion of seed in concentrated sulphuric acid disrupts the seed coat. However, Shabir et al., (2010) reported higher percentage of germination in $I$. racemosa seeds that were scarified and then treated with gibberellin.

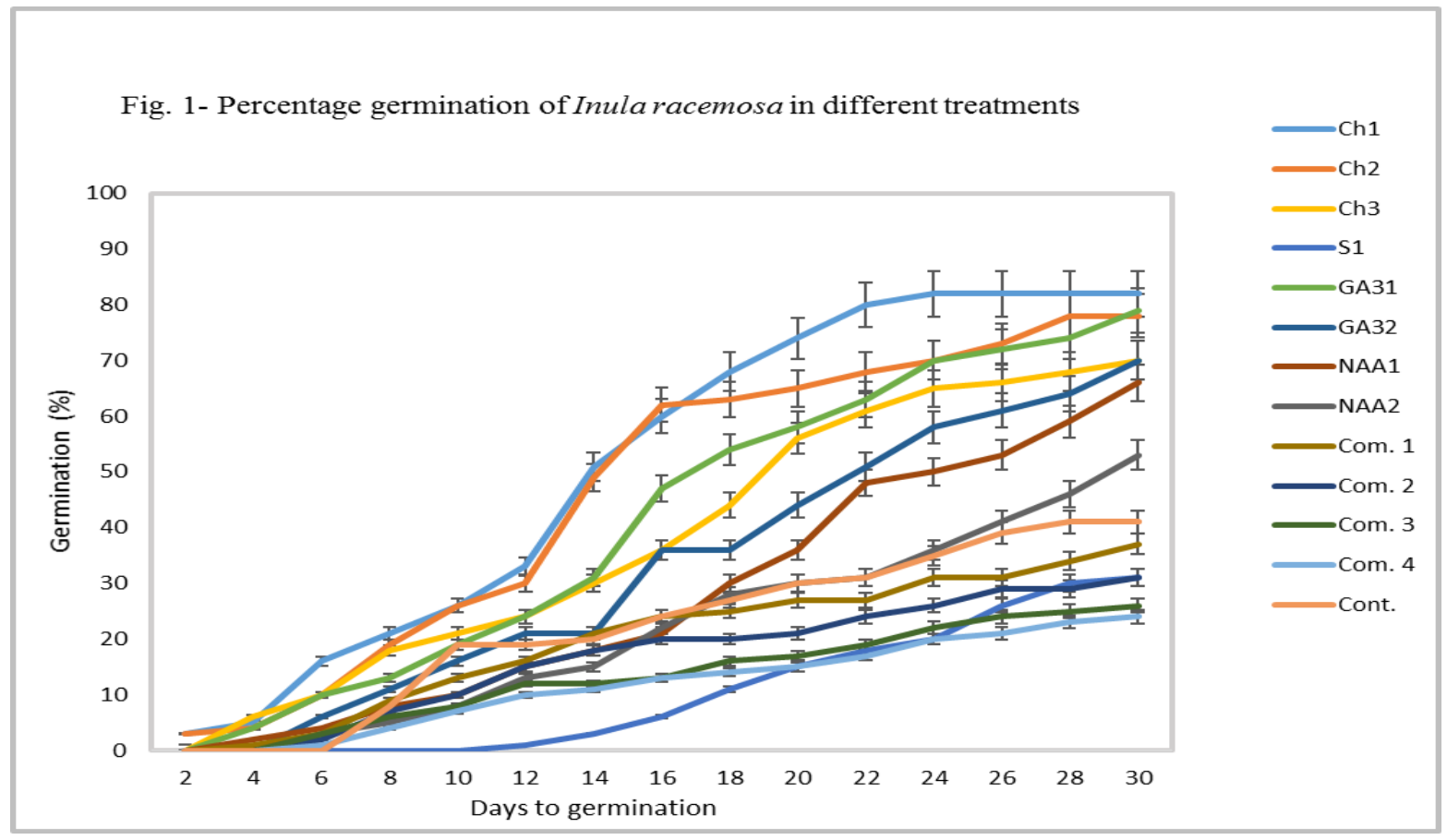

Table.1 Seed germination studies of Inula racemosa Hook. F.

\begin{tabular}{|l|c|c|c|}
\hline Treatments & $\begin{array}{c}\text { No. of days taken for } \mathbf{I}^{\mathbf{s t}} \\
\text { seed to germinate }\end{array}$ & $\begin{array}{c}\text { No. of days taken for last } \\
\text { seed to germinate }\end{array}$ & $\begin{array}{c}\text { Total no. of days taken for } \\
\text { complete germination }\end{array}$ \\
\hline $\mathbf{C h}_{\mathbf{1}}$ & 1 & 26 & 26 \\
\hline $\mathbf{C h}_{\mathbf{2}}$ & 1 & 30 & 30 \\
\hline $\mathbf{C h}_{\mathbf{3}}$ & 3 & 32 & 30 \\
\hline $\mathbf{S}_{\mathbf{1}}$ & 11 & 28 & 15 \\
\hline $\mathbf{G A}_{\mathbf{3}} \mathbf{1}$ & 4 & 30 & 27 \\
\hline $\mathbf{G A}_{\mathbf{3}} \mathbf{2}$ & 5 & 33 & 29 \\
\hline NAA1 & 4 & 30 & 27 \\
\hline NAA2 & 6 & 31 & 26 \\
\hline Com 1 & 5 & 30 & 26 \\
\hline Com 2 & 6 & 30 & 25 \\
\hline Com 3 & 6 & 30 & 25 \\
\hline Com 4 & 6 & 29 & 24 \\
\hline Cont. & 8 & 39 & 32 \\
\hline
\end{tabular}

$\{$ Chilling treatment $(\mathrm{Ch}),: \mathrm{Ch} 1=30$ days, $\mathrm{Ch} 2=40$ days, $\mathrm{Ch} 3=50$ days: Potassium nitrate $(\mathrm{K})$ with $\mathrm{K} 1=0.2 \%, \mathrm{~K} 2=$ 0.3\%: Gibbrellic acid $\left(\mathrm{GA}_{3}\right)$ with $\mathrm{GA}_{3} 1=10^{-3} \mathrm{M}$ and $\mathrm{GA}_{3} 2=10^{-4} \mathrm{M}$ : Combination of sulphuric acid and $\mathrm{GA}_{3}(\mathrm{Com})$, Com $1=\mathrm{H}_{2} \mathrm{SO}_{4} / \mathrm{GA}_{3} 1$, Com $2=\mathrm{H}_{2} \mathrm{SO}_{4} / \mathrm{GA}_{3} 2$ : Sulphuric acid treatment $=\mathrm{S} 1$ : Control $=$ Cont. $\}$ 
Table.2 Statistical parameters of seed germination of Inula racemosa during different day intervals

\begin{tabular}{|l|l|l|l|}
\hline Day intervalls & Critical difference & standard error $(\mathbf{d})$ & Coefficient of variation \\
\hline Day 2 & 0.43 & 0.21 & 64.55 \\
\hline Day 4 & 1.06 & 0.51 & 43.12 \\
\hline Day 6 & 2.20 & 1.07 & 29.04 \\
\hline Day 8 & 2.66 & 1.30 & 18.50 \\
\hline Day 10 & 3.20 & 1.56 & 15.69 \\
\hline Day 12 & 3.82 & 1.86 & 14.68 \\
\hline Day 14 & 3.67 & 1.79 & 11.00 \\
\hline Day 16 & 4.93 & 2.40 & 11.50 \\
\hline Day 18 & 4.36 & 2.12 & 8.97 \\
\hline Day 20 & 3.84 & 1.87 & 7.05 \\
\hline Day 22 & 4.81 & 2.34 & 8.01 \\
\hline Day 24 & 4.66 & 2.27 & 7.13 \\
\hline Day 26 & 4.18 & 2.03 & 6.02 \\
\hline Day 28 & 4.03 & 1.96 & 5.53 \\
\hline Day 30 & 3.43 & 1.67 & 4.468 \\
\hline
\end{tabular}

Table.3 Mean percentage of germination on $28^{\text {th }}$ and $30^{\text {th }}$ day of seed treatment

\begin{tabular}{|l|c|c|}
\hline Treatment & Mean \pm S.E. & Mean \pm S.E. \\
\hline $\mathbf{C h}_{\mathbf{1}}$ & $82.00 \pm 1.15$ & $82.00 \pm 1.15$ \\
\hline $\mathbf{C h}_{\mathbf{2}}$ & $78.00 \pm 1.15$ & $78.00 \pm 1.15$ \\
\hline $\mathbf{C h}_{\mathbf{3}}$ & $68.00 \pm 1.15$ & $70.00 \pm 1.15$ \\
\hline $\mathbf{S}_{\mathbf{1}}$ & $30.00 \pm 1.15$ & $31.00 \pm 1.15$ \\
\hline GA $\mathbf{1}$ & $74.00 \pm 1.15$ & $79.00 \pm 1.73$ \\
\hline GA3 & $64.00 \pm 1.15$ & $70.00 \pm 1.15$ \\
\hline NAA1 & $59.00 \pm 2.30$ & $66.00 \pm 1.15$ \\
\hline NAA2 & $46.00 \pm 0.57$ & $53.00 \pm 1.15$ \\
\hline Com 1 & $34.00 \pm 1.155$ & $37.00 \pm 0.57$ \\
\hline Com 2 & $29.00 \pm 2.30$ & $31.00 \pm 1.15$ \\
\hline Com 3 & $25.00 \pm 0.57$ & $26.00 \pm 0.57$ \\
\hline Com 4 & $23.00 \pm 1.73$ & $24.00 \pm 1.15$ \\
\hline Cont. & $41.00 \pm 2.30$ & $41.00 \pm 2.30$ \\
\hline C.D. & 4.03 & 3.43 \\
\hline SE(d) & 1.96 & 1.67 \\
\hline C.V. & 5.53 & 4.46 \\
\hline
\end{tabular}

\{Chilling treatment $(\mathrm{Ch}), \mathrm{Ch} 1=30$ days, $\mathrm{Ch} 2=40$ days, $\mathrm{Ch} 3=50$ days: Potassium nitrate $(\mathrm{K})$ with $\mathrm{K} 1=0.2 \%$, $\mathrm{K} 2=$ $0.3 \%$ : Gibbrellic acid $\left(\mathrm{GA}_{3}\right)$ with $\mathrm{GA}_{3} 1=10^{-3} \mathrm{M}$ and $\mathrm{GA}_{3} 2=10^{-4} \mathrm{M}$ : Combination of sulphuric acid and $\mathrm{GA}_{3}(\mathrm{Com})$, Com $1=\mathrm{H}_{2} \mathrm{SO}_{4} / \mathrm{GA}_{3} 1$, Com $2=\mathrm{H}_{2} \mathrm{SO}_{4} / \mathrm{GA}_{3} 2$ : Sulphuric acid treatment $=\mathrm{S} 1$ : Control $=$ Cont .

In conclusion, it is recommended that the most practical and useful pre-treatments for propagation of Inula racemosa are the prechilling treatment for a period of 40 days at low temperature $\left(3-4^{\circ} \mathrm{C}\right)$, and treatment with $\mathrm{GA}_{3}$. As in $I$. racemosa low temperature requirement is replaced by $\mathrm{GA}_{3}$. The plant species could be produced in bulk quantity 
when the seeds are treated with $\mathrm{GA}_{3}$. The application of $\mathrm{GA}_{3}$ has also resulted in the reduction of germination time period from 22.5 months to a month.

\section{References}

Agraeber, K., Nakabayashi, K., Miatton,E., Metzger, G. L. and Soppe, W. J. 2012. Molecular mechanisms of seed dormancy. Plant Cell Environment. 35(10): 1769-1786.

Ali, A. and Helal, A. 1996. Studies on germination of Rumex dentatus L. seeds. J. of Arid Environments. 33:3947.

Anonymous. Threatened Medicinal plants of Himalaya-A check list of CAMP Workshop, Lucknow.1998

Aticia, O., Agar, G. and Battal, P. 2003. Interaction between endogenous plant hormones and $\alpha$ - Amylase in germinating Chickpea seeds under Cadmium exposure. Fresenius Environ. Bulleting. 12: 781-785.

Bakrim, A., Lamhamdi, M., Sayah, F. and Chib, F. 2007. Effects of plant hormones and 20-hydroxyecdysone on tomato (Lycopersicum esculentum) seed germination and seedlings growth. African J. Biotech. 6(24): 2792-2802.

Baskin, J.M. and Baskin,C.C.2014. Seeds Ecology, Biogeography and Evaluation of Dormancy and Germination. Academic Press, San Diego.

Baskin, C.C. 2001. Seeds: Ecology, biogeography and evolution of dormancy and germination. Nordic J. of Bot. 20(5): 598.

Bhardwaj, A.K., Kapoor, S., Naryal, A., Bhardwaj, P., Warghat, A.R., Kumar, B. and Chaurasia, O.P. 2016. Effect of various dormancy breaking treatments on seed germination, seedling growth and seed vigour of medicinal plants. Tropical plant research. 3(3): 508516.

Bhavaprakasha Nighantu. 1961. Chowkamba
Sanskrit Series Publication, Varanasi, $\mathrm{p}$ 246.

Bretzloff, L.V. and Pellett, N. 1979. Effect of stratification and gibberllic acid on the germination of Carpinus caroliniana Walt. Hort Science, 14: 621-622.

El-Dengawy, E.R.F. 2005. Promotion of seed germination and subsequent seedling growth of loquat (Eriobotrya japonica Lindl) by moist-chilling and GA3 applications. Scientia Horticulturae, 105(3): 331-342.

Fang, S., Wang, J., Wei, Z. and Zhu, Z. 2006. Methods to break seed dormancy in Cyclocarya paliurus (Batal) Iljinskaja. Scientia Hrticulturae, 110(3): 305-309.

Firdous, Q., Bhat, M.F. and Hussain M. M. 2018. Ethnopharmacology, phytochemistry and biological activity of Inula racemosa HOOK. F: A REVIEW. Int. J. Res. Ayurveda Pharm. 9 (1): 95-102.

Gutterman, Y. 2012. Seed germination in desert plants. Springer Science \& Business Media.

He, Q., Liu, X. C., Sun, R.Q., Deng, Z.W., Du, S. S and Liu, Z.L. Mosquito Larvicidal Constituents from the Ethanol Extract of Inula racemosa Hook. f. Roots against Aedes albopictus. Journal of Chemistry. 6 Pp. http://dx.doi.org/10.1155/2014/ 738796.

Hojati, Y., Naderi, R., Faramarzi, A. and Gholipour, A. 2007. Evaluation the effect of Sulfuric acid, GA3 and temperature treatments on seed germination of Cycas revolute. Journal of Agricul. Modern Science. 9: 13-22.

Kand Kandari, Z.L.S., Roa, K.S., Chauhan, K., Maikihuri, R.K., Purohit, V.K., Phondani, P.C. and Saxena, K.G. 2007. Effect of presowing treatments on seed germination of two endangered medicinal herbs of the Himalaya (Angelica glauca Edgew and Pleurospermum angelicoides wall.EX DC. Benth. Ex C.B Clarke). Proc. Indian Natiomal Science Academy. 73:11-16. 
Khaleghi, A., Dehghan, A. and Moalemi, N. 2009. Effects of Sulfuric acid and hot water treatments on germination properties of Tamarind and Acacia seeds. Journal of Iranian Hort. Science. 40(3): 71-77.

Kyauk, H., Hopper, N.W. and Brigham, R.D. 1995. Effects of temperature and presoaking on germination, root, length and shoot length of sesame (Sesamum indicum L.) Environmental and Experimental Botany. 35: 345-351.

Levitt, J. 1974. Introduction to plant physiology. CV Mosby Company USA. pp. 277-286.

Lewis, W.H. and Lewis, M.P.E. 1977. Introduction to plant physiology. CV Mosby Company USA. pp. 277-286.

Pérez-Fernández, M.A., Calvo-Magro, E., Montanero-Fernández, J. and OyolaVelasco, J.A. 2006. Seed germination in response to chemicals: Effect of nitrogen and $\mathrm{pH}$ in the media. Journal of Environmental Biology. 27(1):13-20.

Maku, J.O., Gbadamosi, A. E. and Oke, S. A. 2014. Effect of Some Growth Hormones on Seed Germination and Seedling Growth of Tetrapleura tetraptera (Thaub). International Journal of Plant Research. 4(1): 36-42.

Nadeem, M., Paln, L.M.S., Purohit, A.N., Pandey, H. and Nandi, S.K. 2002. Propagation and conservation of Podophyllum hexandrum royle: an important medicinal herb Biological Conservation. 92: 121-129.

Nadjafi,F., Bannayan, M., Tabrizi, L. and Rastgoo, M. 2006. Seed germination and dormancy breaking techniques for Ferula gummosa and Teucrium polium. Journal of Arid Environment. 64: 542547.

Nasiri, M. and Eisavand, H.R. 2001. Evaluation the effect of Sulfuric acid on dormancy break and germination of Albizia julibrissin and Ceratonia siliqua seeds. Iranian Journal of Genetic and Breeding Researches of Pasture and Forest Plants. 8: 95-111.
Nego, J., Dechassa, N. and Dessalegne, L.2015. Effect of Seed Priming with Potassium Nitrate on Bulb Yield and Seed Quality of Onion (Allium Cepa L.), under Rift Valley Conditions, Central Ethiopia. International Journal of Crop Science and Technology. 1(2): 1-12.

Nikoleave,M.G.1977. Factors controlling seed dormancy pattern. North Holland publishing Co, Amsterdam. pp 51-74.

Parvaiz, A.W., Kursheed, A.G., Irshad, A.N. and Wafai, B.A. 2006. Phenological episode and reproductive strategies of Inula racemosa (Asteraceae) - A critically endangered medicinal herb of western Himalayas. International Journal of Botany. 2(4).

Pérez-Fernández, M.A. and RodríguezEcheverría, 2003. Effect of smoke, charred wood and nitrogenous compounds on seed germination of ten species from woodland in CentralWestern Spain. J. Chem. Ecol. 29: 237251.

Pharmacopoeia Committee of the Ministry of Health PsRoC (ed) 1995. The Pharmacopoeia of People's Republic of China. Publishers of Guangdong series.12.

Yang,Q.H., Wei,X. and Zeng,X.L.2008. Seed biology and germination ecophysiology of Camellia nitidissima. Forest Ecology and Management. 255(1): 113-118.

Rajareddy,K. and Sudarshanam, G. 1987. Plants used in veterinary medicine in chittoor district of Andhra pradesh, India. Pharmaceutical Biology. 25: 145- 152.

Ramji,S., Singh, R.P., Batliwala, P.G., Upadhyay, B.N. and Tripathy, S.N. 1991. Pushkar aguggulu an anti anginal and hypolipidemic agent in coronary heart disease. J Res Ayur Siddh XII: 118

Saied, A.S., Gebauer, J. and Buerkert, A. 2008. Effects of different scarification methods on germination of Ziziphus spina-christi seeds. International Seed Testing Association. 36(1): 201-205.

Salisbury, F.B. and Ross, C.W. 1992. Plant 
Physiology, fourth ed. Wadsworth Publishing Company, Belmont, CA,p. 682.

Seth,S ., Maulik, M., Katiyar, C. and Maulik, S .1998. Role of Lipistat in Protection against Isoproterenol Induced Myocardial Necrosis in Rats: A Biochemcial and Histopathological Study. Indian journal of physiology and pharmacology.42:101-106.

Seth,S., Maulik, M., Katiyar, C. and Maulik, S .2002. Wealth of India-Raw Materials, First Suppl Ser, Vol IIII. NISCAIRCSIR, New Delhi, p 337.

Shabir, P.A., Nawchoo, I.A. and Wani, A.A. 2010. Development of vegetative and sexual multiplication protocol for commercialization of Inula racemosa Hook. f. - a critically endangered medicinal plant of N.W. Himalaya. Nature and Science. 8(10).

Sharma, R.K., Sharma, S. and Sharma, S.S. 2006. Seed germination behavior of some medicinal plants of Lahaul and Spiti cold desert (Himachal Pradesh): implications for conservation and cultivation. Current Science. 90(8): 1113-1118.

Shinde, H.J., Desai, U.T. and Masalkar, S.M. 1994. Effect of plant growth regulators to control vine length in watermelon. Journal of Maharashtra Agricultural University. 19: 150-151.

Tripathi, S., Tiwari, C., Upadhyay, B. and
Singh, R.1979. Screening of hypoglycemic action in certain indigenous drugs. Journal of Research in Indian Medicine, Yoga and Homeopathy .14: 159-169.

Tripathi, S., Upadhyaya, B. and Gupta, V. 1983. Beneficial effect of Inula racemosa (pushkarmoola) in angina pectoris: a preliminary report. Indian journal of physiology and pharmacology ,28 (1), 73-75.

Uwaegbute, A. C. 1996. African locust bean. In: Food from legumes and Oil seeds pp. 21-23.

Wani, P. A., Ganaie, K.A., Nawchoo,I.A. and Wafai, B.A. 2006. Phenological Episodes and Reproductive Strategies of Inula racemosa (Asteraceae)-a Critically Endangered Medicinal Herb of North West Himalaya. Int. J of Bot. 2(4).

Huang, Z., Zhang,X., Zheng,G. and Gutterman,Y.2003. "Influence of light, temperature, salinity and storage on seed germination of Haloxylonammodendron," Journal of Arid Environments. 55 (3), pp: 453-464. Zhang, S.D., Jiang-Jiang Qin, J.J., Hui-Zi Jin, H.Z., Yin-Hua Yin, Y.H., Li, H.L., Yang, X.W., Li, X., Shan, L. and Zhang, W. D. 2012. Sesquiterpenoids from Inula racemosa Hook. f. Inhibit Nitric Oxide Production. Planta Medica, 78: 166-171.

\section{How to cite this article:}

Haleema Bano, Javeed I.A. Bhat, F.A. Lone, Faisal Noor, M. Ashraf Bhat and Nageena Nazir. 2019. Effect of Phytohormones and Other Dormancy Breaking Chemicals on Seed Germination of Inula racemosa Hook F. - A Critically Endangered Medicinal Plant of North Western Himalaya. Int.J.Curr.Microbiol.App.Sci. 8(03): 866-876. doi: https://doi.org/10.20546/ijcmas.2019.803.104 